\title{
PENGARUH REKOMENDASI BLOGGER TERHADAP MINAT BELANJA ONLINE
}

\author{
Fallane Hartanto \\ Program Studi Magister Manajemen Universitas Tarumanagara \\ fallanehartanto@gmail.com \\ Eko Harry Susanto \\ Program Studi Magister Manajemen Universitas Tarumanagara
}

Masuk : 27-11-2020, revisi : 14-12-2020 diterima untuk diterbitkan : 15-12-2020

\begin{abstract}
This research aims to determine the effects of blogger recommendations on online shopping interestions from attractiveness, trust and expertise. The number of samples used in this study were 215 consumer respondents who are active in online shopping in Jakarta, Indonesia. This research uses quantitative research type, by distributing questionnaires online through google form media with purposive random sampling method and analysis techniques using Partial Least Square (PLS). The results of this research indicate that there is an effect of attractiveness, trust and expertise on online shopping interest. This research is expected to provide insight into the understanding the interest in online shopping.
\end{abstract}

Keywords: Online Shopping, Attractiveness, Trust, Expertise, Bloggers

\begin{abstract}
Abstrak: Penelitian ini bertujuan untuk mengetahui pengaruh rekomendasi blogger terhadap minat belanja online yaitu menilai dari daya tarik, kepercayaan dan keahlian. Jumlah sampel yang digunakan dalam penelitian ini sebanyak 215 responden konsumen yang aktif dalam belanja online di Jakarta. Penelitian ini menggunakan jenis penelitian kuantitatif, yaitu dengan cara penyebaran kuesioner secara online melalui media google form dengan metode purposive random sampling dan teknik analisis menggunakan Partial Least Square (PLS). Hasil penelitian ini menunjukkan bahwa adanya pengaruh daya tarik, kepercayaan dan keahlian terhadap minat belanja online. Penelitian ini diharapkan dapat memberikan wawasan dalam pemahaman minat belanja online.
\end{abstract}

Kata Kunci: Belanja Online, Daya Tarik, Kepercayaan, Keahlian, Blogger

\section{PENDAHULUAN}

Perkembangan teknologi internet dapat membantu dan mengubah berbagai aspek dari sosial, ekonomi, dan budaya secara signifikan berlangsung sangat cepat, terutama akses internet ini sudah dirasakan oleh seluruh masyarakat dalam menjalani kehidupan sehari-hari yang memudahkan dalam berkomunikasi, memperoleh informasi hingga berbelanja online. Belanja online merupakan proses pembelian barang atau jasa oleh pembeli kepada penjual melalui internet, yang biasa disebut toko virtual (Didit Agus Irwantoko, 2012). Belanja online bertujuan untuk meningkatkan minat pembelian konsumen yang didukung oleh teknologi internet sehingga dapat menarik perhatian para konsumen dari warna, gambar, bentuk, suara, pelayanan dan ketersediaan yang dapat memikat minat konsumen untuk membeli produk atau jasa dari situs online (Sophia, 2014). Minat pembelian dalam belanja online merupakan suatu situasi saat pelanggan bersedia dan berminat untuk terlibat dalam transaksi online tersebut.

Di era globalisasi ini, perubahan gaya pemasaran pun terjadi dengan menampilkan konsumen-konsumen jenis baru (Suryani, 2013) yaitu pemasaran masuk (inbound marketing) yang telah menjadi pilihan terbaik daripada pemasaran tradisional yang monoton misalnya perusahaan harus membeli ruang iklan (televisi, radio, iklan media cetak) serta menunggu ada pelanggan yang datang bertanya. Inbound marketing sejalan dengan teknologi era digital 
karena dapat dilakukan dengan mempergunakan sarana dan teknik seperti blog dan media sosial. Berdasarkan IAB Spanyol 2016 menyatakan bahwa blog beserta rekomendasi dari mulut ke mulut (WOM) antara keluarga dan teman merupakan influencer terbesar dalam sebuah pengambilan keputusan untuk pembelian barang. Dari perspektif pemasaran, blogging telah dipandang sebagai jenis baru word-of-mouth elektronik (eWOM) (Osman et al., 2009) telah ditetapkan bahwa persepsi kredibilitas blogger pada akhirnya mengarah pada adopsi konsumen atas rekomendasi eWOM (Cheung et al., 2009).

Beberapa penelitian telah menunjukkan bahwa rekomendasi pengguna di blog dapat menghasilkan efek pemasaran yang kuat untuk menjangkau konsumen. Dikarenakan transaksi online tidak dilakukan secara langsung, konsumen memerlukan informasi yang andal dan bermanfaat untuk lebih memahami produk dan selanjutnya mendukung keputusan pembelian mereka. Dalam sebuah studi Ohanian (1991) menemukan bahwa konsep "Online Consumer Review" mempunyai tiga dimensi variabel yang terdiri dari Daya Tarik, Kepercayaan dan Keahlian.

\section{Tujuan Penelitian}

Tujuan dari penelitian ini adalah (1) mengetahui pengaruh daya tarik dari rekomendasi blogger terhadap minat belanja online, (2) mengetahui pengaruh kepercayaan dari rekomendasi blogger terhadap minat belanja online dan (3) mengetahui pengaruh keahlian dari rekomendasi blogger terhadap minat belanja online.

\section{TINJAUAN PUSTAKA}

Rekomendasi blogger dapat menciptakan efek daya tarik pemasaran yang tinggi untuk dapat menjangkau konsumen membeli produk tertentu. Dalam konteks perspektif pemasaran ini, rekomendasi blogger telah dipergunakan sebagai jenis yang baru dari word-of-mouth elektronik (eWOM) (Osman et al., 2009). Menurut Cheung et al., 2009, persepsi kredibilitas seorang blogger mengarahkan kepada adopsi konsumen atas rekomendasi eWOM bahkan reputasi seorang blogger sebagai kredibilitas sumber juga dapat dianggap menjadi salah satu faktor yang mempengaruhi keputusan konsumen untuk membeli produk. Park dan Lee (2009) mengatakan jikalau konsumen akan lebih cenderung percaya pada eWOM yang disahkan mengenai sebuah produk jika berasal dari sumber yang sangat terpercaya yaitu situs web yang terkenal. Studi perilaku konsumen tersebut menjelaskan bahwa suatu kelompok referensi akan mempengaruhi perilaku pembelian konsumen (Bearden dan Etzel, 1982; Childers dan Rao, 1992; Engel et al., 1993). Rekomendasi dari kelompok memiliki peran penting dalam keputusan konsumen terutama saat membeli produk yang bernilai tinggi (mahal). Oleh karena ini, untuk mengurangi risiko yang besar serta ketidakpastian dalam pembelian, konsumen akan bergantung kepada saran dari lingkungan sekitar untuk memantau evaluasi dari pembelian tersebut (Brown dan Reingen, 1987; Kotler, 1999). Jika diamati dengan saluran pemasaran yang bersifat formal seperti periklanan ternyata rekomendasi dari blogger ialah saluran pemasaran informal yang secara positif menhubungkan antar konsumen (FIND, 2005). Saluran komunikasi ini memiliki sifat dua arah dengan adanya interaksi langsung dari sang blogger dengan konsumen sehingga rekomendasi blogger dapat lebih bernilai berharga dan terpercaya daripada informasi komersial yang hanya satu arah (Bernoff dan Li, 2008, Wu, 2011). Secara empiris, Lim et al. (2006) menjelaskan bahwa dukungan konsumen yang puas secara signifikan akan mempengaruhi pembelian konsumen lainnya.

Beberapa tahun terakhir ini, blog dan media sosial telah menjadi saluran paling terkenal untuk mendiskusikan ide dan pendapat yang berkaitan mengenai kejadian di kehidupan seharihari. Singer 2009 mengatakan bahwa rata-rata 900.000 artikel baru per hari diunggah di blog bahkan secara khusus, banyak orang membuat blog komentar setelah menggunakan produk tertentu. Menurut laporan myYearbook (Wegert, 2010), 81 persen para konsumen mencari beberapa saran sebelum akan melakukan transaksi lewat situs online dan 74 persen konsumen yang menerima saran tersebut melakukan pembelian dan mereka berhasil mempengaruhinya 
sehingga rekomendasi blogger dapat menjadi salah satu faktor terpenting sebelum membuat keputusan pembelian konsumen. Istilah yang umum digunakan untuk menggambarkan karakteristik positif komunikator yang mempengaruhi penerimaan pesan oleh penerima termasuk berbagai dimensi, seperti kepercayaan keahlian, dinamisme, objektivitas, keselamatan, kualifikasi, kompetensi, daya tarik, dapat dipercaya dan kemampuan bersosialisasi. Skala kredibilitas sumber tersebut telah dikembangkan oleh Ohanian pada tahun 1990 yang mencakup dimensi daya tarik, kepercayaan, dan keahlian yang mempunyai keandalan dan validitas nomologis, konvergen, dan diskriminan. Menurut Ohanian (1990) mengenai dampak dari tiga komponen kredibilitas ialah dimensi online customer review, dilihat dari:

(1) Daya tarik merupakan acuan pada seseorang yang dianggap menarik perhatian untuk dipandang dan dilihat secara fisik maupun non fisik. Nadia dan Lidia (2016) mengungkapkan bahwa daya tarik ialah usaha daya tarik secara fisik seorang bintang yang digunakan untuk periklanan yang bertujuan untuk meningkatkan minat beli konsumen. Seseorang yang secara fisik menarik perhatian akan lebih menghasilkan tayangan iklan yang menyenangkan daripada iklan yang mempergunakan komunikator yang kurang atraktif. Daya tarik soerang endorser maupun blogger meliputi dari tingkat keramahan, kesenangan, pekerjaan dan fisik. Daya tarik fisik seseorang dapat dilihat dari penampilan fisik maupun luar dari gaya orang tersebut seperti karakteristik yang menarik perhatian, cantik, classy, elegant dan sexy. Seorang komunikator yang menarik secara fisik akan mempunyai dampak yang positif pada perubahan opini seseorang dan evaluasi produk tersebut (Spry, 2009). Solomon et al (1992) menyatakan bahwa daya tarik dapat meningkatkan perasaan suka terhadap minat beli konsumen, bahkan Kamin (1990) juga berpendapat bahwa daya minat berpengaruh positif menjadi pembawa pesan dan sikap terhadap iklan tertentu.

(2) Kepercayaan merupakan sebuah kesediaan untuk menjadikan pribadi yang peka dalam suatu tindakan yang dipilih oleh pihak yang dipercaya berdasarkan pada keyakinannya. Ohanian (1990) mengatakan bahwa sebuah kepercayaan adalah derajat keyakinan seseorang dengan tingkat penerimaan seseorang terhadap influencer beserta pesan yang ingin disampaikan. Menurut Loggerenberg, Waldt dan Wehmeyer (2009) bagian terbesar dari kepercayaan terletak pada kesukaan terhadap influencer. Kepercayaan sebagai sebuah kesediaan dari konsumen untuk menerima kerentanan dalam melakukan transaksi online yang didasarkan pada harapan yang positif mengenai perilaku berbelanja online pada masa mendatang (Kimery dan McCard dalam Suryani 2013). Menurut Chin-Lung Hsu, Judy ChuanChuan Lin, Hsiu-Sen Chiang, (2013), kepercayaan dianggap sebagai salah satu yang faktor penting dalam stimulant terhadap transaksi secara online. Ketika kepercayaan tersebut sudah semakin tinggi akan membuat ukuran untuk meningkatkan minat beli konsumen untuk berbelanja secara online.

(3) Keahlian merupakan sebuah tingkatan seorang komunikator dalam mempersepsikan sebagai sumber dengan pernyataan yang dipercaya dan handal yang memberikan opini yang bersifat obyektif tentang subjek tersebut. Keahlian juga dapat diartikan suatu kemampuan influencer dalam memberikan informasi valid yang berasal dari pengetahuan, pelatihan, pengalaman dan keterampilan yang dimiliki influencer (Abednia et al.2011). Shimp (2007:205) mengatakan bahwa keahlian mengacu pada pengetahuan dan pengalaman yang dimiliki seorang blogger yang dihubungkan oleh merek yang didukungnya. Seorang blogger yang sudah diterima sebagai seorang yang memiliki keahlian pada merek tersebut akan lebih persuasif dalam hal menarik perhatian konsumen dibandingkan seorang blogger yang tidak memiliki keahlian tertentu. Tingkat pengetahuan atau keahlian blogger merupakan detereminan utama dari kredibilitas sumber ungkap karena tingkat pengetahuan tentang subjek tersebut yang harus dikuasai (Engel et. al. 1995:87). Hal ini mengacu pada pengetahuan komunikator harus mendukung atas pernyataan yang disampaikan dalam rekomendasinya (Avery, 1998). 
Kerangka pemikiran dalam penelitian ini seperti digambarkan dibawah ini:

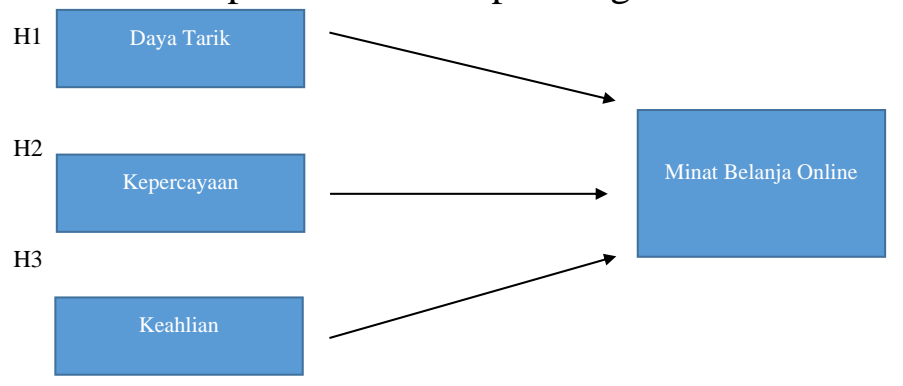

Gambar 1

Kerangka Pemikiran

Hipotesis dari model yang dibangun di atas adalah sebagai berikut:

H1: Terdapat pengaruh daya tarik terhadap minat belanja online.

$\mathrm{H} 2$ : Terdapat pengaruh kepercayaan terhadap minat belanja online.

H3: Terdapat pengaruh keahlian terhadap minat belanja online.

\section{METODOLOGI PENELITIAN}

Subjek penelitian yang dilakukan dalam penelitian ini merupakan konsumen yang aktif berbelanja online dengan menyebarkan ke 215 responden terbagi atas pria sebesar 89 responden $(41,4 \%)$ dan wanita sebesar 126 responden $(58,6 \%)$. Sebagian besar responden berusia 20-25 tahun sebanyak 133 responden (61,9\%), usia $>25$ tahun sebanyak 62 responden $(28,8 \%)$ dan paling sedikit berusia $<20$ tahun yaitu 20 responden $(9,3 \%)$. Teknik pengambilan sampel untuk menentukan sampel yang akan digunakan dalam penelitian ini adalah teknik purposive random sampling dengan objek penelitian: daya tarik, kepercayaan, keahlian dan minat belanja online. Dalam penelitian ini menggunakan analisis data dengan menggunakan SmartPLS inner model sebagai berikut: $Q$-squared $\left(\mathrm{Q}^{2}\right)$, Koefisien Determinasi $\left(\mathrm{R}^{2}\right)$ dan Goodness of Fit Index (GoF) sedangkan pengujian hipotesis menggunakan metode PLS-SEM dengan melihat nilai $t$-statistic, $p$-value dan path coefficient.

\section{HASIL DAN KESIMPULAN}

Berdasarkan hasil analisis dengan menggunakan uji Q-squared terdapat hasil output Q2 sebesar 0.180, skor Q2 > 0 menunjukkan variabel ini mampu memprediksi model dengan baik. Uji selanjutnya adalah Koefisien Determinasi yang digunakan untuk mengetahui persentase sumbangan variabel bebas secara serentak terhadap variabel terikat menunjukkan angka 0.284. Jadi, dapat disimpulkan bahwa 28,4\% dapat dijelaskan oleh variabel dependen yaitu daya tarik, kepercayaan dan keahlian serta sisanya dapat dijelaskan oleh variabel-variabel lainnya. Ketiga ada uji Goodness of Fit Index dengan menggunakan rumus GoF $=\sqrt{A V E x R} 2$ ditemukan hasil sebesar 0.429 yang berarti nilai GoF memiliki tingkat keseuaian model yang besar. Analisis PLS-SEM dapat dilihat dengan nilai t-statistic, $p$-value dan path coefficient yang terdapat pada analisis jalur antar variabel melalui metode bootstrapping. Daya tarik memiliki nilai t-statistic sebesar $3.671>$ cut-off value 1.96 dan nilai $p$-value $<0.05$ yaitu sebesar 0.000 serta memiliki hubungan yang bersifat positif sebesar 0.231. Kepercayaan memiliki nilai t-statistic sebesar $2.347>$ cut-off value 1.96 dan nilai p-value $<0.05$ yaitu sebesar 0.019 serta memiliki hubungan yang bersifat positif sebesar 0.196. Keahlian memiliki nilai t-statistic sebesar $2.672>$ cut-off value 1.96 dan nilai $p$-value $<0.05$ yaitu sebesar 0.008 serta memiliki hubungan yang bersifat positif sebesar 0.216 . Hasil analisis tersebut dapat dilihat pada tabel dibawah ini:

Tabel 1

Hasil Pengujian Hipotesis Penelitian

\begin{tabular}{|c|l|c|c|c|c|}
\hline \multicolumn{2}{|c|}{ Kode Hipotesis } & Path Coef & Std.Deviation & t-statistics & p-values \\
\hline H1 & Daya Tarik -> Minat Belanja Online & 0.231 & 0.063 & 3.671 & 0.000 \\
\hline H2 & Kepercayaan -> Minat Belanja Online & 0.196 & 0.084 & 2.347 & 0.019 \\
\hline H3 & Keahlian -> Minat Belanja Online & 0.216 & 0.081 & 2.672 & 0.008 \\
\hline
\end{tabular}


Hasil analisis menunjukkan H1 diterima bahwa daya tarik dari blogger berpengaruh terhadap minat belanja online dikarenakan daya tarik dapat meningkatkan perasaan suka terhadap minat beli dan menjadi pembawa pesan dan sikap terhadap iklan tertentu. Konsumen akan meniru blogger dengan daya tarik fisik yang dianggapnya menarik dan akan memberikan dampak persuasi bagi orang yang melihatnya (Louie. et al dan ford et. al.,2002).

Hasil analisis menunjukkan $\mathrm{H} 2$ diterima bahwa kepercayaan dari blogger berpengaruh terhadap minat belanja online dikarenakan budaya kaum kolektivis orang Asia memiliki minat kolektif atas kepentingan individu dengan cara berkelompok, mendengar pendapat orang lain untuk berafiliasi dengan orang lain dan menjaga hubungan baik. Adanya penekanan kolektivis pada hubungan dengan orang lain, maka diperlukan rasa kepercayaan antar pribadi (Deshpande \& Stayman, 1994).

Hasil analisis menunjukkan $\mathrm{H} 3$ diterima bahwa keahlian dari blogger berpengaruh terhadap minat belanja online dikarenakan persepsi yang dirasakan oleh blogger secara signifikan menjelaskan minat subyek untuk membeli produk. Tingkat keahlian blogger ialah detereminan utama dari kredibilitas sumber ungkap karena tingkat pengetahuan tentang subjek tersebut yang harus dikuasai keahlian akan mengarah kepada anggapan tentang sumber pesan yang sudah mempunyai kemampuan untuk bisa menyampaikan informasi yang akurat dan terpercaya.

\section{DAFTAR PUSTAKA}

Beneke. (2016). An application of sweeney's risk-price-quality-value framework through a consideration of store brand merchandise. Journal of Business and Retail Management Research, 106-176.

Chakraborty, U. (2019). The impact of source credible online reviews on purchase intention. Journal of Research in Interactive Marketing, 142-161.

Curvelo, I. C. (2019). Purchase intention of organic food under the influence of attributes, consumer trust and perceived value. Revista de Gestão, 198-211.

Hanaysha, J. R. (2018). An examination of the factors affecting consumer's purchase decision in the Malaysian retail market. PSU Research Review, 7-23.

Hsu, C. L. (2013). The effects of blogger recommendations on customers' online shopping intentions. Internet Research, 69-88.

Keller, K. L. (2009). Management Marketing. Jakarta: Erlangga.

Lin, H. L. (2018). Influence of multiple endorser-product patterns on purchase intention. International Journal of Sports Marketing and Sponsorship, 415-432.

Ling, K. C. (2010). The effects of shopping orientation, online trust and prior online purchase experience toward customers' online purchase intention. International Business Research.

McGuire, W. (1985). Attitudes and attitude change. In G. Lindzey \& Aronson (Eds.), Handbook of Social Psychology, 233-346.

Mehmet Turan, A. K. (2018). Online social media usage behavior of entrepreneurs in an emerging market. Journal of Research in Marketing and Entrepreneurship.

Ohanian, R. (1990). Construction and validation of scale to measure celebrity endorsers perceived expertise, trustworthiness, and attractiveness. Journal of Advertising, 39-52.

Ohanian. (1991). Construction and validation of scale to measure celebrity endorsers perceived expertise, trustworthiness, and attractiveness. Journal of Advertising.

Pornpitakpan, D. C. (2014). The effect of celebrity endorsers' perceived credibility on product purchase intention. Journal of International Consumer Marketing, 55-74. 